\title{
LV. Reply to Mr. H. B. Lesson
}

\section{J. Murray F.L.S. M.W.S.}

To cite this article: J. Murray F.L.S. M.W.S. (1822) LV. Reply to Mr. H. B. Lesson, Philosophical Magazine Series 1, 59:288, 251-253, DOI: 10.1080/14786442208652732

To link to this article: http://dx.doi.org/10.1080/14786442208652732

$$
\text { 曲 Published online: } 29 \text { Jul } 2009 .
$$

Submit your article to this journal

LII Article views: 2

Q View related articles ¿ 


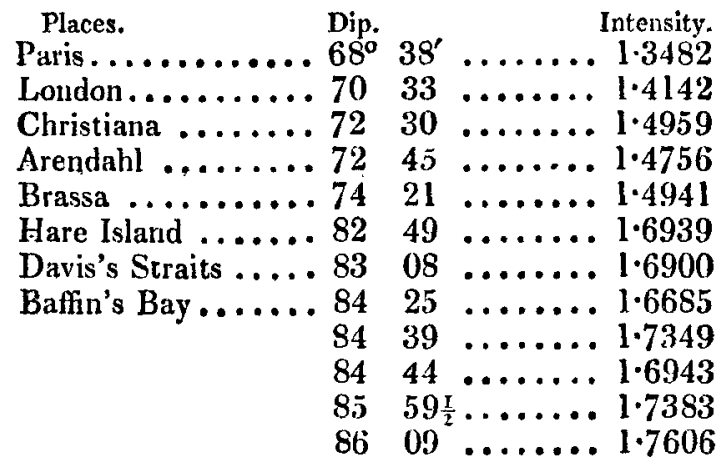

LV. Reply to Mr. H. B. Leeson. By J. Murray, F.L.S. M.W.S. Eீc. Eீc.

\section{To Dr. Tilloch.}

SIR, - I Have neither time nor inclination for any thing controversial, and least of all do I wish to disturb Mr. Leeson's tranquillity, in reference to $h i s$ "Safety Appendages" to Toft's Hydrostatic Blowpipe. My remarks therefore on his last paragraph, which includes notice of me, shall be succinct.

The use of mercury is conceded to me as recommended on the plan of Marquis Ridolfi; but it should seem either that I had omitted to state the necessity of a cell to contain it, or was ignorant that iron alone was proof against the action of quicksilver-Credat Judceus apella. 'The following are the words used by Mr. L. in a letter to me, dated I8th January last : "You told me that mercury had been adopted (employed?) by the Marquis Ridolf, and that you thought it preferable to oil or water; on which I observed that the cylinder must in that case be made of iron!"

When at Florence, this interesting young nobleman was good enough to sketch with his own hand, though labouring under a severe accident, the consequence of chemical experiment, the attachment to the gas blowpipe, to which the preceding refers. You had the kindness to insert in your pages a copy of this sketch and its description. Mr. Leeson might have there seen this described as of iron.

Mr. Toft's blowpipe was constructed at Nottingham, under Mr. Leeson's directions; when funished, the instrument was charged with an explosive atmosphere, and at the orifice of Dr. Hope's Safety Box of Wire-gauze (certainly proof against all explosion, nor can I tow warmly recommend its use) the gaseous 
mixture burnt tranquilly. It was unscrewed, and the gas ignited at the extremity of a capillary tribe; the flame receded, an explosion ensued, and the instrument was destroyed. Mr. Leeson's "valve therein" was a common button valve. This is the circumstance which Mr. L. would inform us of at page 403 of your December Number.

Having said thus much for the safety cistern, I shall now advert to the "valve therein."

From the explosion adverted to, which $\mathrm{Mr}$. L. ascribed to the valve being rudely made, I concluded that some other plan of the valve was advisable, though $\mathrm{Mr}$. Leeson thought the same valve repaired would do. The plan I proposed is now introduced in Mr. Leeson's own words, quoted also from his letter of 18th January. It was submitted before Mr. L. to one Andayna for such alteration and improvement as he saw necessary.

"Your plan of two button valves, to be connected together by a solid spindle up the sides of which the gas was to pass, and which were to be rendered airtight by two pieces of leather attached to their under surfaces, and the buttons were to be prevented from rising too high by two small bits of wire inserted above the upper valve." This may perchance be pronounced not a "modification" of that to which we find "H. B. Leeson invt. et del." attached. But there is no doubt of its being equally safe-by this provision of a double guard both valves closing simultaneously.

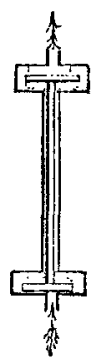

Allow me to ask, sir, why this anxiety to entertain us with different arrangements of the "Safety cistern and valve therein?" The bundle of wires deposited in the cell serves all the purposes of the wire-gauze with which Mr. L. now crams the cistern; and under such circumstances, which is merely placing Dr. Hope's wire-gauze box within the cistern, instead of exterior to it, the instrument would be safe without any valve al all; aye, or even mercury.

I own that I was much amused with " experiment" and "explosion," nay, "repetitions" of them, so loudly vaunted in Mr. Leeson's "6 new observations ;" being sadly sceptical, whether coming from this young gentleman, I am to regard them vox et prcetcrea nihil. Mr. Leeson in a letter to me (13th November) advised "a good way of trying the Safety Appendages," -" to connect them with a bladder containing the explosive mixture, set a candle before the jet and open the cock of the jet-pipe by a long string!" Are we to understand that his " experiments," "explosions," and "repetitions," were made in this manner?

I honestly confess that I am sorry for having written the note 
annexed to Mr. Leeson's paper, and thus to ruffle his quiet. It must however be obvious that $I$ had no interest in doing so. The iron cistern and mercury belong to Marquis Ridolfi; the cane and fasces of wires belong to Dr. Clarke and yourself; the multiplied folds of wire-gauze to Dr. Hope, and the valve say to Mr. H. B. Leeson.

I have the honour to be, sir,

Your obedient humble servant,

J. Murray.

LVI. Comparison of the Expense attending the English and Scotch Systems of Husbandry. By Mr. ANDREW SCOTT, of Ryden's Farm, Wallon-upon-Thames *.

I

HAVE the honour of presenting to the Board of Agriculture some statements on the oeconomy of the Scotch system of farming, which I practise, and proceed to state the difference of expense between the English and Scotch modes of farming. The first circumstance which I have to notice, is, that my ploughing is performed with two horses, instead of three. 'This, besides saving the keep of a horse, also saves the expense of a boy, an appendage always required when three horses are put to a plough. The keep of a horse cannot be stated at less than $45 \mathrm{l}$. per annum; and a boy at $5 s$. a week, is $13 l$. But from the boy being sometimes employed in harrowing, driving dung, \&.c. in which cases a boy is also required upon the other system, it would be unfair to charge the full amount of his wages; $8 l$. however, out of the $13 l$. I think, ought to be calculated upon, which, with the sum charged for the leep of a horse, makes $53 \mathrm{l}$. ; and as on the rotation I follow, a plough cannot manage more than fifty acres, a saving is thereby gained of a trifle more than $21 s$. per acre. It may be added, that iny lands, as well as most of those in this neighbourbood, consist of a sandy or hazel loam, and such as two horses, at all seasons, are abundantly able to plough; but there are clays in this county, where four and six horses are put to a plough, and where two would be altogether insufficient, particularly in the summer season, when they are baked with the drought. I however think, that, by adopting the use of another plough, the number of horses may be reduced at least one-third, and during a greater part of the year onchalf.

A measure very properly connected with the two-horse plough is the using of one-horse carts, instead of those in general use requiring three horses. With the latter a greater weight than

* From Communications to the Board of Agriculture. 